the previous year recorded, in order to draw conclusions from our spraying.

Mr. G. W. Herrick: In this case we do not know definitely except that the crop during the previous year was a failure.

A Member: May I ask if this ground was heavy clay?

Mr. G. W. Herrick: It was clay soil mixed with gravel and quite stony.

A Member: It has been my experience that cherries are not infested so much on clay soil.

Mr. G. W. Herrick: There are a good many cherry trees not far from this orchard, but the iatter are rather isolated. The fly does not seem to travel very far. The feeding habits of this species are practically the same as those of the house-fly as given in Dr. Howard's book on this subject. The flies are constantly sucking from the fruit which shows the manner in which they get their food from the fruit and leaves.

\title{
SOME EXTERNAL INSECT PARASITES OF DOMESTIC FOWLS
}

GlenN W. Herrick

Domestic fowls, especially the hen, constitute one of the most important sources of food supplies in America. It is amazing to find that during 1911 the value of poultry in the United States reached a total of $\$ 154,663,220$ and the value of the eggs produced in the same year in New York State alone amounted to the astonishing sum of $17,102,000$ dollars. It is evident that poultry occupies an important place in the life economies of the American people and any pests injuriously affecting domestic fowls are worthy of careful consideration. The study of the external parasites of domestic fowls has extended over several years with many interruptions and delays. It has been difficult to collect the different species infesting fowls and even yet we have not been able to obtain all the species that I feel surely exist in the United States.

According to the different authorities on Mallophaga there are at least eight species infesting the hen, four or five the goose, three or four the turkey, four the duck, four the pea fowl, three the guinea hen, and seven the pigeon.

In addition to the Mallophaga we find that there are in this country at least eighteen species of mites parasitic on the domestic fowl, two species of fleas, one fowl-bug, one tick, and possibly one fly.

Among these parasites the Mallophaga hold the most interest for the author. Some of the most interesting questions of development, 
variation, etc., arise out of a consideration of the geographical and host distribution of these parasites. They are wingless insects of worldwide distribution existing wherever members of the bird tribe are found. They are parasites that live for their whole life on the body of their host. They, of course, migrate from one host to another when the hosts are in actual contact, when in copulation; when brooding over the offspring; or when huddling together on perches. Moreover there is occasionally an opportunity for the parasites of a host to actually migrate to a host of another species. For example, we find a certain species of hen louse on the turkey, especially when the two species of domestic fowls are in the same yard. We have also found two species of hen lice on guinea hens where the latter were allowed to frequent the perches and houses of the hens. Kellogg has found the same species of louse on both a cormorant and a pelican shot on the rocky shores of the Pacific Coast where these two species of birds congregated and evidently came in actual contact. But as Kellogg further points out another explanation must be given for the distribution of those species of Mallophaga that are found on birds of the Old World and on closely related birds of the New World. There are many instances of this kind, yet these birds do not come in contact, nor within thousands of miles of each other. Kellogg offers an exceedingly interesting explanation of this phenomenon in distribution. He says, "that the parasitic species has persisted unchanged from the common ancestor of the two or more now distinct but closely allied bird-species." That is to say, these species of Mallophaga existed on the ancestors of the host birds and have persisted ever since without change although their hosts have become modified into different species. This may be explained by the fact that the Mallophaga are surrounded by an environment, namely, the feathers, skin, and temperature of the host, that do not change although the host itself may change. These are not economic questions perhaps but they are intensely interesting ones.

The more important question from an economic point of view is how these parasites injure poultry. The Mallophaga have biting mouth parts and do not suck the blood of their host. In fact, it is doubtful if any of the Mallophaga parasitic on domestic fowls ever get any blood except in case of a wound or bruise on the host from which the blood may issue. In such instances the parasites may eat the dried scales of blood. Blood has been found in some instances in the stomachs of bird lice, probably obtained in the manner just described. Kellogg notes a species of Mallophaga that lives inside of the pouch of the California Brown pelican and clings to the wall of the pouch by its mandibles. Moreover, he has found a small area. 
surrounding the parasites raw and bloody. It is a question in this case as to what these particular lice eat for food.

It is generally conceded that Mallophaga live upon bits of feathers and scales of the skin. Theobald speaks of them as constantly biting at the skin and causing serious irritation. Other writers hold that the constant movements of the lice cause irritation to the skin by reason of the sharp claws, with which all the feet of these parasites terminate. The presence of the lice sets up an irritation and pruritus that eventually weaken the host and give a chance for various maladies to get hold of the fowl. This seems to be especially true of chicks, where, if the lice are abundant, growth is greatly checked, diarrhoea seems to follow and a general weakened condition may result.

The losses caused by the poultry lice are difficult to estimate but the total must be large. Chickens, when badly infested, fail to make anything like their normal growth. Theobald gives the results of some expcriments showing that chicks suffering from lice, at the end of the year, weighed one pound less than those which had been kept free from these pests, both having had exactly the same diet.

The loss in egg production through the infestation of laying hens must be enormous although there is no way of getting even an approximation. Brood-hens are often so irritated by these parasites that many of the failures in hatching must be attributed to the lice. Undoubtedly the presence of the lice, by weakening the general constitutions of their hosts, predisposes the fowls to such diseases as gapes, cholera, roup, etc., and thus contributes to a formidable indirect loss and injury.

\section{List of Mallopiaga on Domestic Fowls}

The species marked with a ${ }^{*}$ have been collected and are thus known to occur in this country.

On the Hen (Gallus domesticus)

*Meñopon pallidum Nitzsch.

* Menopon biseriatum Piaget.

*Lipeurus helerographus Nitzsch.

${ }^{*}$ Lipeurus rariabilis Nitzsch.

Goniodes dissimilis Nitzsch.

Goniodes eymsfordii Theobald.
*Goniocoles gigas Taschenberg.

*Goniocotes abdominalis Piaget.

Probably a synonym of $G$. gigas.

${ }^{*}$ Goniocoles hologasler Nitzsch.

Goniocotes burnettii Pack.

Probablya synonym of $L$. heterographus.

On the Turkey (Meleagris gallopavo)

*Coniodes slylifer Nitzsch. - Menopon stramineum Nitzsch.

*Lipeurus polytrapezius Nitzsch. Probably a synonym of biseriatum.

*Menopon biseriatum Piaget.

On the Goose (Anser domesticus)

Lipeurus anseris Gurlt.

*Lipeurus jejunus Nitzsch.

*Trinolon conspurcatum Nitzsch.
*Trinolon lituratum Nitzsch.

*Docophorus icterodes Nitzsch. 
On the Duck (Anas domesticus)

*Lipeurus squalidus Nitzsch.

*Lipeurus helerographus Nitzsch.

*Docophorus icterodes Nitzsch.

On the Pea Fowl (Pavo cristatus)

*Menopon phositomum Nitzsch.

*Goniodes falcicornis Nitzsch.
* Menopon obscurum Piaget.

*Trinoton luridum Nitzsch.

\section{On the Guinea Fowl (Numida meleagris)}

Menopon numidice Denny. Lipeurus numidice Denny. Goniodes numidianus Denny.

\section{On the Pigeon (Columba domestica)}

*Colpocephalum longicaudum Nitzsch.

*Goniocotes compar Nitzsch.

*Lipeurus baculus Nitzsch.

Goniodes damicornis Nitzsch.
*Goniocoles abdominalis Piaget.

*Menopon pallidum Nitzsch.

In addition to the Mallophagan parasites we should like to record the definite occurrence of the hen flea (Ceratophyllus gallino) more commonly known as Pulex avium in this country. Doctor Taschenberg records it from a great variety of birds including domestic fowls but, so far as the writer is aware, it has been recorded from this country but once and that was by Baker in Canad. Ent., Vol. 27, p. 111, under the name Pulex avium. This single specimen was contributed by Prof. Herbert Osborn and was collected at Ames, Iowa, but the host was not given.

In the spring of 1912 , specimens of this flea were received from Abington, Mass., with an inquiry concerning them and methods of getting rid of them. The specimens were taken from the inside walls and roof of a poultry house but were not collected directly from the fowls. The correspondent informed me that the fleas had bitten her so severely that the bites troubled her for two or three weeks afterwards. The fleas had not been noticed until a few weeks after the purchase of some chickens from a neighbor who had just returned from California. It is thus barely possible that the fleas had been imported from California although the correspondent did not think the neighbor had brought any fowls from that state.

The specimens were submitted to Baron Rothschild of England who determined them as the hen flea, Ceratophyllus gallince.

President W. D. Hunter: If there is no further business, adjournment will be in order.

Adjournment. 
Afternoon session, Thursday, January 2, 1.30 p. m.

President W. D. Hunter: The first paper on the program will be presented by Mr. H. J. Quayle on, "Some Natural Enemies of Red Spiders."

\section{SOME NATURAL ENEMIES OF SPIDERS AND MITES}

By H. J. Quayle

Red spiders and mites, exposed as they usually are throughout their lives on the surface of the leaves or fruit, and not being very active, are subject to the attacks of a considerable number of enemies. Those that I will consider in this paper were observed to feed upon the spiders and mites of citrus trees in the citrus belt of southern California. The thing that seemed most striking in making these observations was the unusual variety of enemies, insects belonging to groups that we know best as not being predaceous. Thrips are certainly better known as plant enemies rather than as predaceous insects. Likewise members of the family Itonididæ (Cecidomyidæ) are better known on account of their gall-making habits and attacks on living plants, rather than as parasites. Staphylinid beetles are most familiar as feeders on decaying vegetable and animal matter, while a much smaller number are known to be predaceous. All members of the family Coniopterygidæ are predatory, but their habits are so little known that they are no less interesting than the others. In addition to these there are the usual Coccinelids, Hemerobiids, Chrysopids, a predaceous bug (Thriphleps insidiosus), mites and also a secondary Hymenopterous parasite, a chalcid.

The enemies of spiders as thus far investigated in a little corner of the extreme southwestern part of the United States, and only a beginning has been made, include, aside from several species of Acarina, representatives of six insect orders, the Neuroptera, Thysanoptera, Hemiptera, Coleoptera, Diptera and Hymenoptera. I will consider a few of these that are least known.

Conventzia hageni Bks. This Coniopterygid is one of the commonest enemies of spiders in the southern California citrus section. It feeds on the spiders both in the larval and adult stages.

The eggs are of a pinkish yellow color, oval in shape and are deposited singly on the under surface of the leaves. From six to eight. days are required for them to hatch. The larva completes its development in from 18 to 22 days during which time, according to our observations, it molts three times. All stages of the spider are attacked, including eggs, young and adult. In attacking the eggs the mandibles. 